\title{
Early Eocene age of a sandstone from the Buntmergel Formation (Gresten Klippen Zone, Lower Austria)
}

\author{
M. Adam GASIŃSKI, Volker HOECK, Andrzej ŚLĄCZKA and Corina IONESCU
}

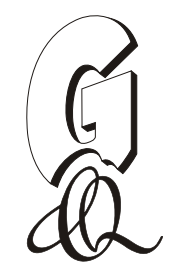

\begin{abstract}
Gasiński M.A., Hoeck V., Ślączka A. and Ionescu C. (2012) - Early Eocene age of a sandstone from the Buntmergel Formation (Gresten Klippen Zone, Lower Austria). Geol. Quart., 56 (4): 845-852, doi: 10.7306/gq.1063

The Gresten Klippen Zone is an individual geological unit, mainly outcropping at the northern rim of the Northern Calcareous Alps. It is best exposed between the Enns Valley in the west and the Vienna Forest in the east. It contains a rock sequence ranging from Early Jurassic to Early Cretaceous, including sandstones, various limestones, breccias and radiolarites. The late Early Cretaceous-Paleogene is represented by the Buntmergel Formation. A sandstone block from the latter yields well-preserved planktonic foraminiferids which allow an assignment to the Early Eocene (E-7 Zone). The low density currents which deposited the parallel laminated sandstones originated in the lower shelf-middle slope.
\end{abstract}

M. Adam Gasiński and Andrzej Ślaczka, Institute of Geological Sciences, Jagiellonian University, Oleandry 2a, 30-063 Kraków, Poland, e-mails: adam.gasinski@uj.edu.pl, andrzej.slaczka@uj.edu.pl; Volker Hoeck, Department of Geography and Geology, Paris Lodron University, Salzburg, Austria and Department of Geology, Babeş-Bolyai University, Cluj-Napoca, Romania, e-mail: volker.hoeck@sbg.ac.at; Corina Ionescu, Department of Geology, Babes-Bolyai University, Cluj-Napoca, Romania, e-mail: corina.ionescu@ubbcluj.ro (received: July 11, 2012; accepted: October 9, 2012; first published online: December 10, 2012).

Key words: Gresten Klippen Zone, Eocene, planktonic foraminiferids, Lower Austria.

\section{INTRODUCTION}

The Gresten Klippen Zone (GKZ), despite being known as an individual geological unit since the mid of 20 th century (Prey, 1952, 1953), is still not completely understood from biostratigraphic and tectonic points of view. It is part of the Helvetic Zone (including the Ultrahelvetic Zone), which extends in the Eastern Alps along the northern rim of the Northern Calcareous Alps, from Vorarlberg in the west to Lower Austria and the Vienna Forest in the east (Prey, 1980). In this paper we provide new insight into the biostratigraphy of the Paleogene part of the Buntmergel Formation (Piller et al., 2004) which belongs to the GKZ in Lower Austria (Fig. 1). The fossil findings presented here come from a single block only, containing very well-preserved foraminiferids. Ongoing research in the Paleogene section focuses on the overall stratigraphic scheme of the whole sequence.

\section{GEOLOGICAL SETTING}

The most complete stratigraphic sequences in the Helvetic and Ultrahelvetic zones, respectively, are found east of Salzburg, in a $75 \mathrm{~km}$ west-east striking area, terminated in the west by the Pechgraben close to the Enns Valley, and in the east by the Traisen Valley (Figs. 1 and 2). This particular area is known as the "Gresten Klippen Zone". Further to the east, it is called the "Hauptklippen Zone". It consists of a predominantly Jurassic sequence forming the "Klippen" and an envelope sequence - the Buntmergel Formation - that ranges from the late Early Cretaceous (Albian) to the Eocene (Fig. 2). The klippen are formed by individual blocks ranging in size from a few metres to several hundreds of metres (Aberer, 1951; Prey, 1953; Schnabel, 1970; Ślączka et al., 2009).

One of the most important sequences in the GKZ is the Gresten Formation of early to mid-Jurassic age that forms the stratigraphically deepest level and has no known basement. 


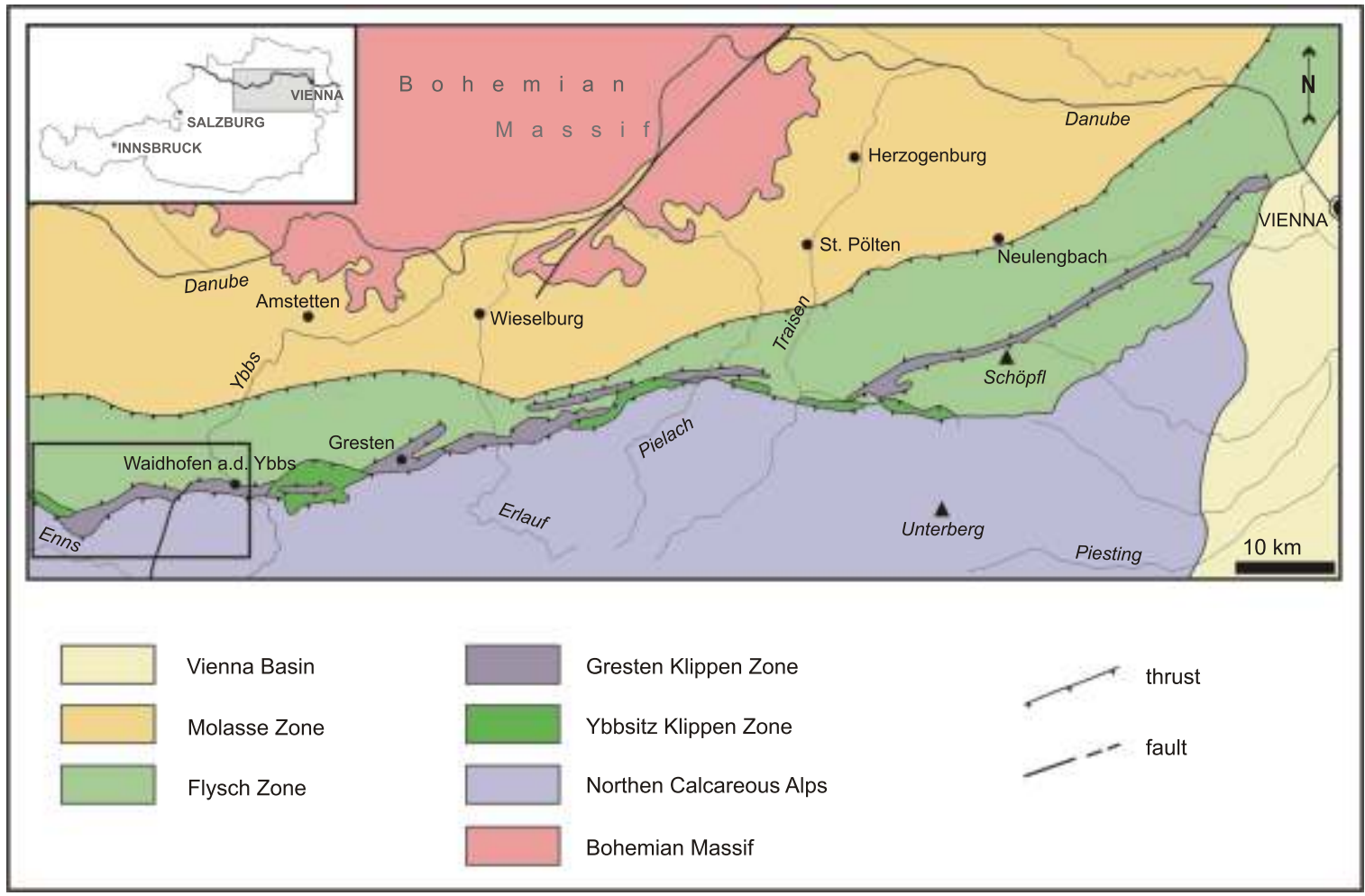

Fig. 1. Simplified geological map of the Gresten Klippen Zone east of Enns

The map is based on the tectonic overview map of Lower Austria by Schnabel (1992) and Schnabel et al. (2002). The insert in the upper left shows the position of the map within Austria. The black rectangle marks the study area (shown in detail in Fig. 2)

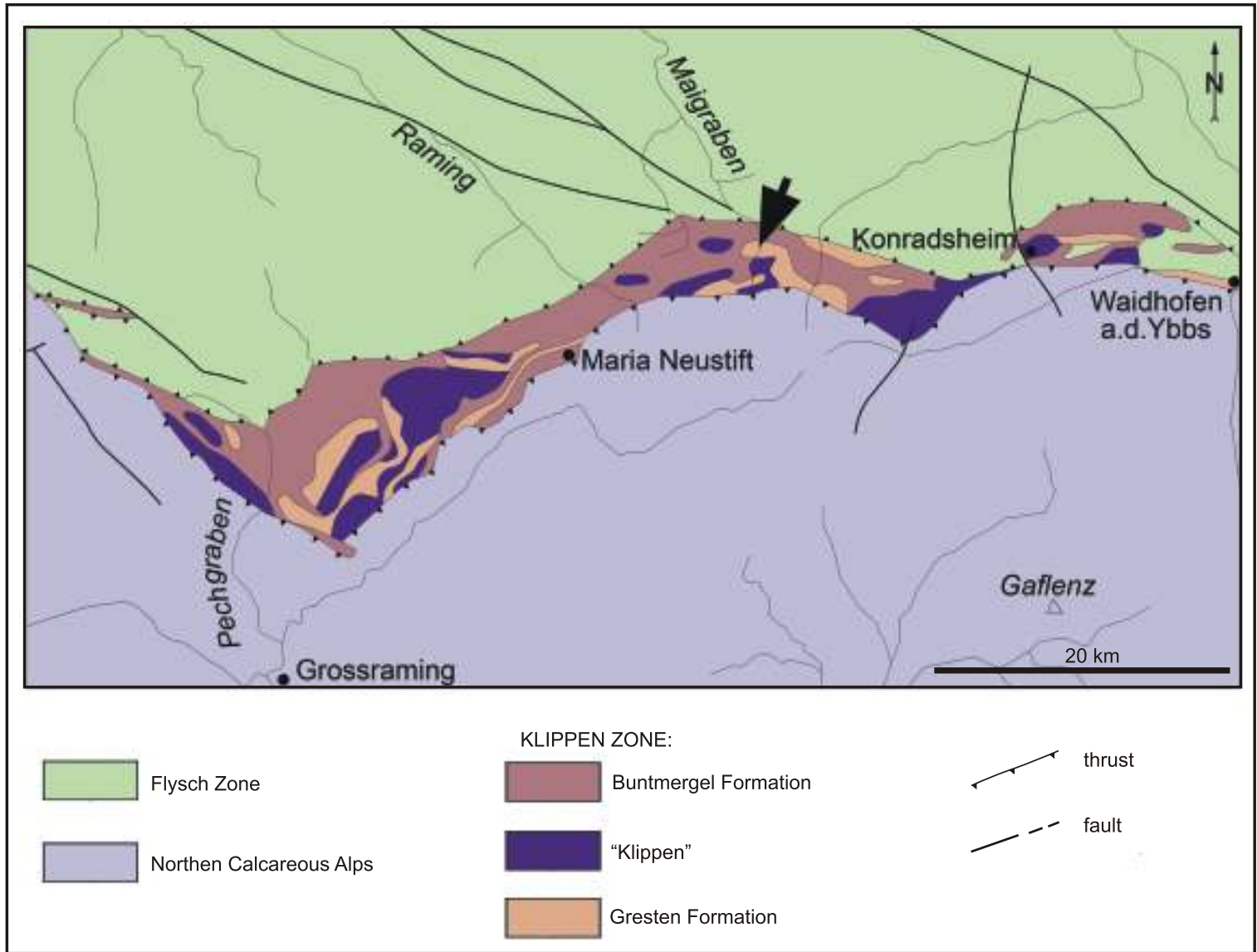

Fig. 2. Simplified geological map of the area of the Gresten Klippen Zone between Pechgraben and Waidhofen a.d. Ybbs, based on Schnabel et al. (2002) 
Faupl (1975) distinguished three major lithofacies: (a) a basal fluvial facies succession, (b) a sequence associated with coals and (c) a marine succession. They grade into a sequence of predominantly grey marls and shales interlayered with sandstones, marly limestones and some coarse clastic deposits (Posidonia marls of Bajocian-Callovian age; Trauth, 1950; Wessely, 2006). These sediments pass into cherty limestones and radiolarites of Middle Jurassic and earliest Oxfordian age (Lampelsberg Formation). The Late Jurassic and the lower part of the Early Cretaceous are represented by siliceous limestones (Scheibbsbach Formation), red nodular Arzberg limestones, dark grey Arthof limestones, Aptychus limestones (Lower Blassenstein Formation) and the spotted marls and marly limestones of the Upper Blassenstein Formation that lasted until the Barremian-Aptian. Within the Tithonian-Barremian deposits, lenses of conglomerates known as the Konradsheim limestones (Faupl, 1975; Widder, 1988; Wessely, 2006) occur. Recently, a sequence of Barremian-Aptian conglomerate was described as the Konradsheim Formation (Höck et al., 2003, 2005; Ślączka et al., 2009).

The contact relation of the Buntmergel Formation with the Late Jurassic-Early Cretaceous carbonate sequence is unclear. Rarely, depositional contacts have been described (Prey, 1980) but in general the contact is tectonically overprinted (Schnabel, 1970; Widder, 1988; Wessely, 2006; Ślączka et al., 2009). The Buntmergel Formation is represented by red to green, rarely grey marls and marly shales with subordinate thin-bedded quartzitic sandstones with glauconite.

During the Early Paleogene, nummulitic limestones, graded sandstones and conglomerates (e.g., Konradsheim conglomerates) were deposited. Within these clastic deposits of Paleogene age, Faupl (1978) distinguished four different facies types: (1) coarse-grained limestone breccia and conglomerates with abundant siliciclastic material ("Bernreith facies"), (2) calcirudite and calcarenite ("Texing facies"), (3) quartz arenite and conglomerate ("Schaitten facies") and (4) a turbidite facies. The marls between the coarse clastic horizons are grey, green, and in places bluish in colour; the typical Upper Cretaceous red marls are missing. Thin layers of glauconitic sandstone are common (Widder, 1988). There are sedimentary breccias of Paleocene age similar to the first facies type described by Faupl and Schnabel (1987) from the Scheibbs area. The lithic fragments in the coarse-grained clastic layers include metagranites, gneisses, various types of micaschists, greenschists, and intermediate to acidic volcanic rocks. They are similar to those found in the Jurassic clastic sequences and indicate a similar hinterland for the Jurassic and Paleogene sediments. Blocks of sedimentary rocks such as chert, Calpionella limestone, Trocholina limestone and Litothamnium limestone with Orbitoides and Nummulites are also present.

\section{RESULTS AND DISCUSSION}

\section{LITHOLOGY OF THE SAMPLE}

The fossiliferous rock piece (Sample S9) was found in the Maigraben in Grossau - an area of the Gresten Formation that outcrops at N47 $57^{\prime} 20^{\prime \prime}$ and E14 $39^{\prime} 07^{\prime \prime}$ - as a loose decimetre-sized block of sandstone (see arrow in Fig. 2).

The Gresten Formation in Grossau is fairly well-known since the second half of the 19th century due to the intensive coal mining (e.g., Lipold et al., 1865). Aberer (1951) described a sequence of grey sandy, occasionally also marly shale, interbedded with sandstones.

In the Maigraben profile, the Gresten Formation, dipping in general towards the south, is directly enveloped by the Buntmergel Formation. The relatively high amount of red marls and the lack of clastic beds in the scarce exposures argue for a Cretaceous section of the Buntmergel Formation (Aberer, 1951).

The sandstone block found in Maigraben is thin bedded, with light brown and medium grey laminae up to several $\mathrm{mm}$ in thickness (Fig. 3A). The light brown layers are relatively rich in
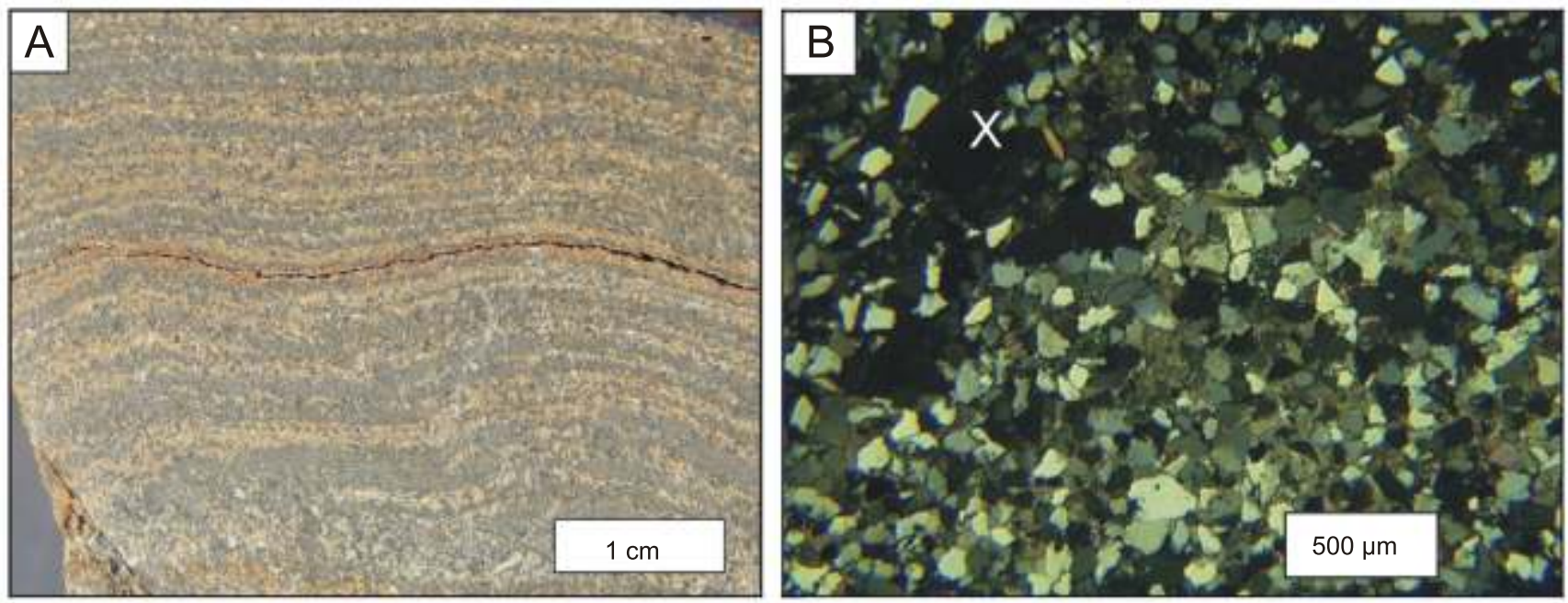

Fig. 3. The sandstone from the Buntmergel Formation

A - macroscopic image, showing the alternation of fine layers of almost pure quartz (medium grey) and quartz + carbonate (light brown); B - crossed polars, light microphotograph, showing fine-grained quartz cemented by calcite; the area marked by X represents the light brown layers rich in calcitic cement, visible in A 

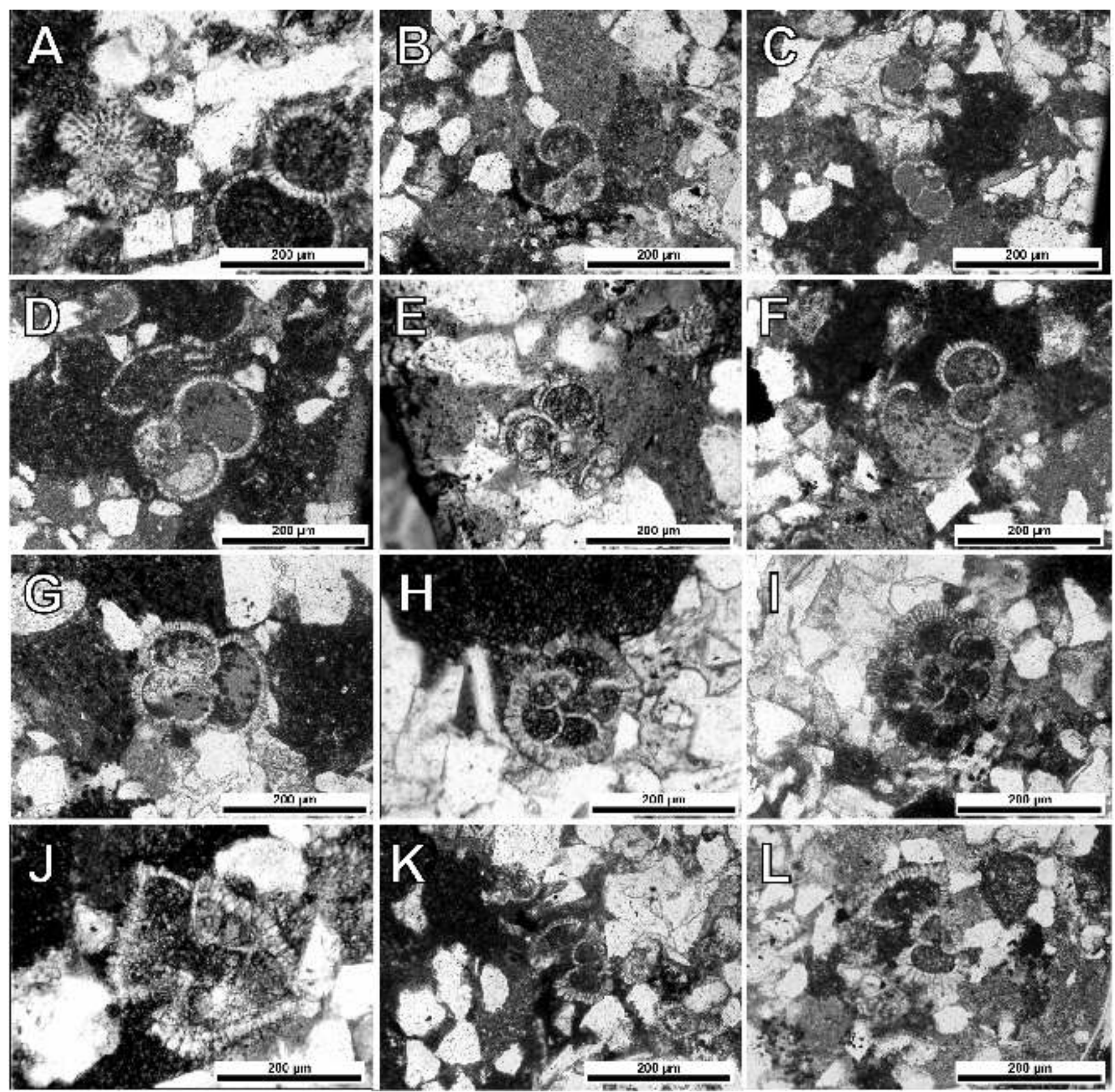

Fig. 4. Planktonic foraminiferids

A - Acarinina sp.; B - Subbotina yeguaensis (Weinzierl and Applin); C - Subbotina sp.; D, E - Acarinina pseudotopilensis Subbotina; F, G Subbotina yeguaensis (Weinzierl \& Applin); H, I - Acarinina cf. bulbrooki (Bolli); J-L - Acarinina bulbrooki (Bolli). A-G - differently oriented sections; H-I - cross-sections; J-L - axial sections

carbonate whereas the medium grey layers consist of predominantly quartz grains with only a small amount of carbonate. Microscopically, it reveals a well-sorted sandstone with angular to subangular grains ranging from 20 to $100 \mu \mathrm{m}$ in size (Fig. 3B). Mineralogically, the sandstone consists of quartz, rare feldspars (mainly plagioclase) and some muscovite and biotite. Glauconite is ubiquitous. The calcitic cement is inhomogeneously distributed within the rock, with a visible concentration in elongated lenses forming thin laminae. These laminae contain very well-preserved, whole foraminiferal tests. Although this sandstone was found in the area of the Gresten
Formation outcrops, it distinctly differs from the sandstones known from the Gresten Formation (Faupl, 1975) by fine laminae, a good sorting, a smaller grain size and the abundance of glauconite. Our sample fits best to the sandstones from the "turbidite facies" of the Buntmergel Formation stratigraphically assigned to late Early Eocene (Faupl, 1978).

\section{MICROPALEONTOLOGY}

The foraminiferids analysed were recognized from the thin section made from the block described above (sample S9). 

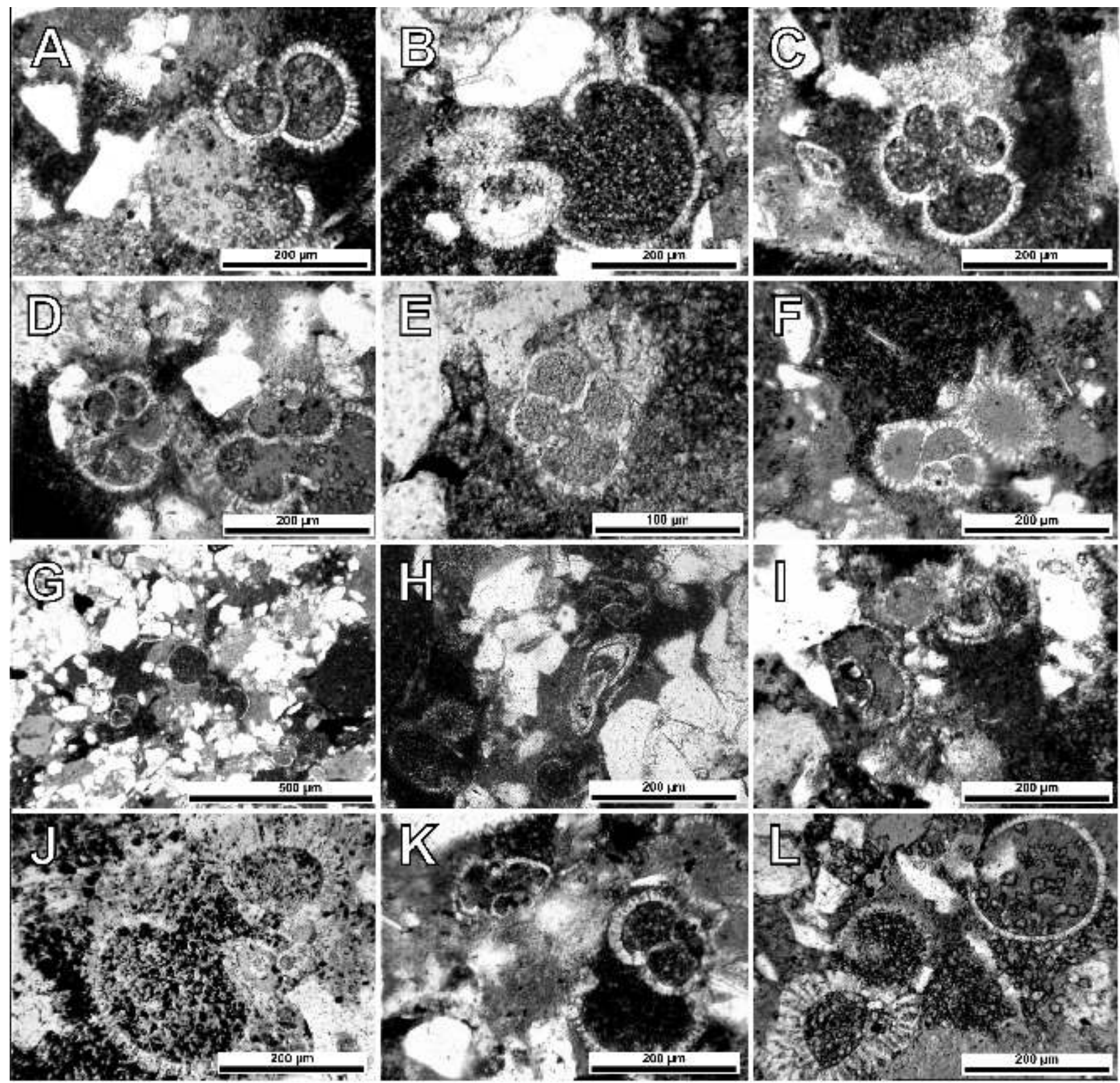

Fig. 5. Planktonic foraminiferids

A, B - Parasubbotina inaequispira (Subbotina); C, D - Acarinina esnehensis (Nakkady); E, F - Subbotina yeguaensis (Weinzierl and Applin), G Globigerina sp. - juvenile forms; $\mathbf{H}$ - Globanomalina sp.; I - Acarinina sp.; J, K - Acarinina esnehensis (Nakkady); L - Acarinina sp. - fragment

They show well-preserved tests. The foraminiferids are well-preserved for several reasons: (a) the containing rocks are only slightly altered and (b) they were transported and emplaced by density currents.

The index planktonic species identified are: Subbotina yeguaensis (Weinzierl and Applin), Acarinina pseudotopilensis Subbotina, Parasubbotina inaequispira (Subbotina), Acarinina bulbrooki (Bolli) and Acarinina esnehensis (Nakkady). All species identified are shown in Figures 4A-L and 5A-L. Undamaged fragile tests are particularly visible in Figure 5G. Some specimens have ornamented test walls (Figs. 4G, J-L and 5A, J) and visible positions of the aperture (Figs. 4F, K, L and 5A, B).

BIOSTRATIGRAPHICAL POSITION

OF THE FORAMINIFERAL ASSEMBLAGE

The rich and well-preserved characteristic planktonic index species allow assignment to a high-resolution biozone level. Figure 6 shows the position of the fossil assemblage within the standard biostratigraphic chart of Pearson et al. (2006). The age of the sample studied can be estimated as late Early Eocene, i.e. E-7 Zone (Berggren and Pearson, 2005), which corresponds to zone 


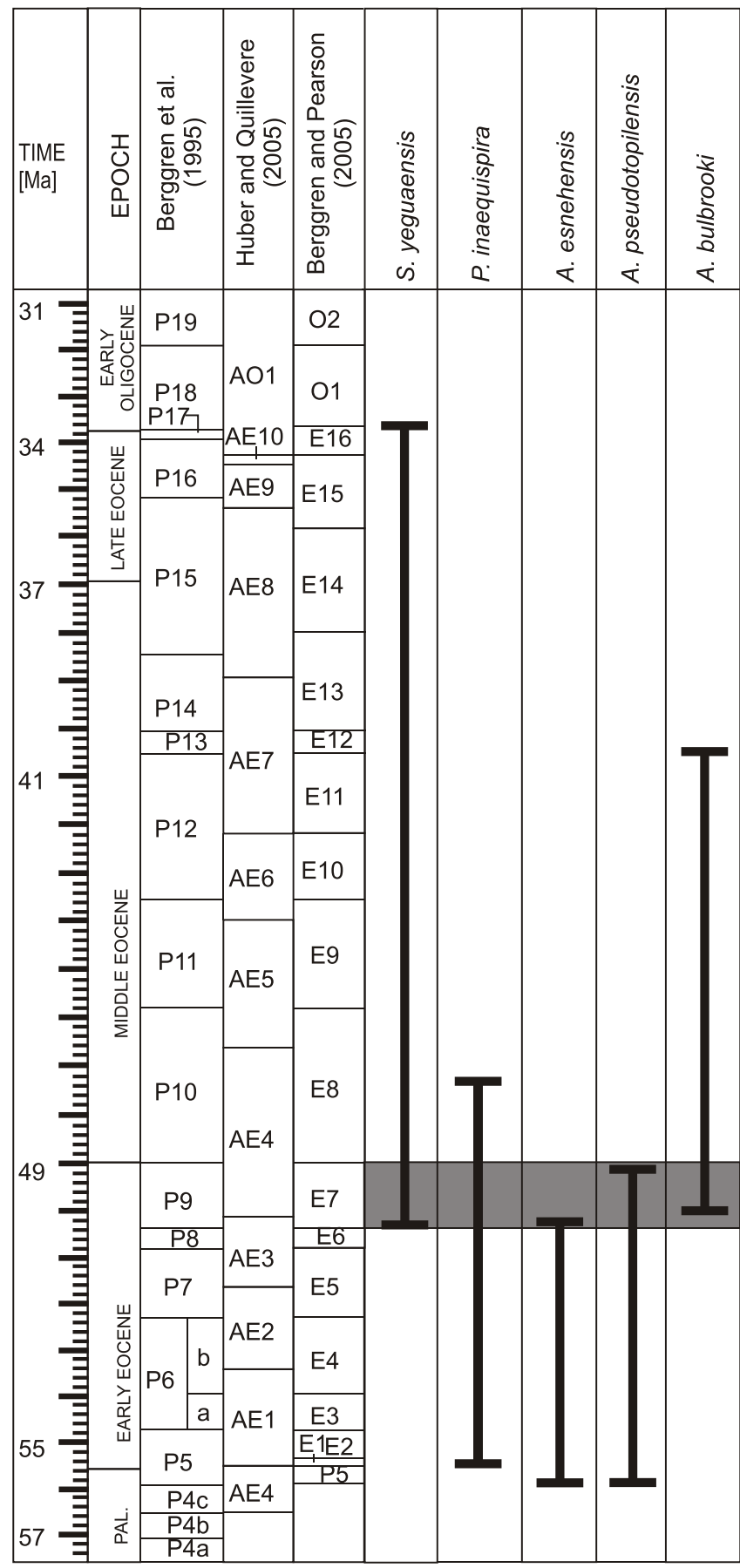

Fig. 6. Biostratigraphical range of the planktonic index taxa identified
P9 sensu Berggren et al. (1995) and to the lower part of AE 4 Zone sensu Huber and Quillievere (2005). The morphotypes of the planktonic taxa, in particular the presence of keeled forms, indicate an external shelf-middle slope depositional (i.e. a bathy-pelagic) environment (Gasiński, 1997).

Due to the sparsity of available material, determination of the depositional environment for the sandstone is difficult. However, the fine laminations, the visible lack of gradation and in particular the well-preserved, undamaged fragile tests of relatively deep-water planktonic foraminiferids argue for sedimentation by low density currents and fallout without traction (Reading, 1996). The laminae show millimetre-sized folds (Fig. 3A), suggesting local syn-sedimentary sliding. Nevertheless, this sandstone can be generally included among the "deep-water turbidite facies" (Reading, 1996).

\section{CONCLUSIONS}

Well-preserved deep sea planktonic foraminiferids occur in a loose sandstone block in the Grossau area (Maigraben) in Lower Austria. The following foraminiferids were found: Acarinina sp., Acarinina pseudotopilensis Subbotina, Acarinina bulbrooki (Bolli), Parasubbotina inaequspira (Subbotina), Acarinina esnehensis (Nakkady), Subbotina sp., Subbotina yeguaensis (Weinzierl and Applin), Globigerina sp. and Globanomalina sp. The perfectly preserved palaeontological features of the foraminiferids allow their precise biostratigraphic assignment to the E-7 Zone of Pearson et al. (2006). Therefore, the block of sandstone can be assigned to the upper, Early Eocene part of the Buntmergel Formation of the Gresten Klippen Zone. The clastic material of the sandstone investigated was primarily deposited on a slope of the basin and later on redeposited by low density currents to deeper parts of the basin. As a result of our studies, new data concerning the clastic deposits from the Eocene part of the Buntmergel Formation have been obtained.

Acknowledgements. We thank Prof. Dr. B. Olszewska and Prof. Dr. T. Peryt (Polish Geological Institute - National Research Institute), and an anonymous reviewer for critical remarks which improved the manuscript. Dr. P. Wójcik-Tabol and W. Obcowski (Institute of Geological Sciences, Jagiellonian University) kindly helped with the illustrations. Mrs. M. Mereu (Babeş-Bolyai University) is thanked for computer-assisted drawings.

The dark grey area marks the biozones identified; graphic chart after Pearson et al. (2006)

\section{REFERENCES}

ABERER F. (1951) - Beiträge zur Stratigraphie und Tektonik der Randzonen der nördlichen Kalkalpen zwischen Neustift und Konradshaim. Mitt. Geol. Ges. Wien, 39-41 (1946-1948): 1-73.

BERGGREN W.A. and PEARSON P.N. (2005) - A revised tropical to subtropical planktonic foraminiferal zonation of the Eocene and Oligocene. J. Foram. Res., 35: 279-298.
BERGGREN W.A., KENT D.V., SWISHER C.C. and AUBRY M.-P. (1995) - A revised Cenozoic geochronology and chronostratigraphy. SEPM Spec. Publ., 54: 129-212.

FAUPL P. (1975) - Kristallinvorkommen und terrigene Sedimentgesteine in der Grestener Klippenzone (Lias-Neokom) von Ober- und Niederösterreich. Jb. Geol. B.-A., 118: 1-74. 
FAUPL P. (1978) - Faziestypen der paläogenen Buntmergelserie der östlichen Ostalpen. Mitt. Österr. Geol. Ges., 68 (1975): 13-38.

FAUPL P. and SCHNABEL W. (1987) - Ein Breccienvorkommen bei Scheibbs (Nieder österreich). Zur Kenntnis paläogener Grobklastika aus der Buntmergelserie. Jb. Geol. B.-A., 130: 153-161.

GASIŃSKI M.A. (1997) - Tethyan-Boreal connection: influence on the evolution of mid-Cretaceous planktonic foraminiferids. Cret. Res., 18: 505-514.

HÖCK V., ŚLĄCZKA A., GASIŃSKI A. and BĄK M. (2003) - The age of the Konradsheim Limestone (Gresten Unit, Austria). Mitt. Österr. Mineral. Ges., 148: 169-170.

HÖCK V., ŚLĄCZKA A., GASIŃSKI A. and BĄK M. (2005) Konradsheim Limestone of the Gresten Klippen Zone (Austria): new insight into its stratigraphic and palaeogeographic setting. Geol. Carpath., 56 (3): 237-244.

HUBER B.T. and QUILLEVERE F. (2005) - Revised Paleogene planktonic foraminiferal biozonation for the Austral Realm. J. Foram. Res., 35: 299-314.

LIPOLD M.V., STUR D., STERNBACH G., RACHOY J. and HERTLE L. (1865) - Das Kohlengebiet in den nordöstlichen Alpen. Jb. Geol. R.A., 15: 1-164.

PEARSON P.N., OLSSON R.K., HUBER B.T., HEMBLEBEN C. and BERGGREN W., eds. (2006) - Atlas of Eocene planktonic foraminifera. Cushman Found. Spec. Publ., 41.

PILLER W.E., EGGER H., ERHART C.W., GROSS M., HARZHAUSER M., HUBMANN B., van HUSEN D., KRENMAYR H.-G., KRYSTYN L., LEIN R., LUKENEDER A., MANDL G.W., RÖGL F., ROETZEL R., RUPP C., SCHNABEL W., SCHÖNLAUB H.P., SUMMESBERGER H., WAGREICH M. and WESSELY G. (2004) Die stratigraphische Tabelle von Österreich 2004 (sedimentäre Schichtfolgen). Österr. Akad. Wiss. u. Österr. Strat. Komm., Wien.

PREY S. (1952) - Aufnahmen in der Flyschzone auf der Blättern Gmunden-Schafberg (4851) und Kirchdorf-Krems (4852), sowie auf den Blättern Ybbs (4754) und Gaming-Mariazell (4854) (Bericht 1951). Verh. Geol. B.-A., 1952: 41-45.

PREY S. (1953) - Flysch, Klippenzone und Kalkalpenrand im Almtal bei Scharnstein und Grünau (O. Ö.). Jb. Geol. B.-A., 96: 301-343.

PREY S. (1957) - Ergebnisse der bisherigen Forschungen über das Molassefenster von Rogatsboden (N. Ö.). Jb. Geol. B.-A., 100: 299-358.

PREY S. (1980) - Helvetikum, Flysche und Klippenzonen von Salzburg bis Wien. In: Der Geologische Aufbau Österreichs (ed. R. Oberhauser): 189-217. Springer, Wien, New York.

READING H. G., ed. (1996) - Sedimentary environments: processes, facies and stratigraphy. Blackwell Science Oxford.

SCHNABEL W. (1970) - Zur Geologie des Kalkalpennordrandes in der Umgebung von Waidhofen/Ybbs, Niederösterreich. Mitt. Ges. Geol. Bergbaustud. Österr., 19: 131-188.

SCHNABEL W. (1992) - New data on the Flysch Zone of the Eastern Alps in the Austrian sector and new aspects concerning the transition to the Flysch Zone of the Carpathians. Cret. Res., 13: 405-419.

SCHNABEL W., KRENMAYR H.-G., MANDL G.W., NOWOTNY A., ROETZEL R. and SCHARBERT S. (2002) - Geological map of Austria 1:200,000 Niederösterreich, mit Erläuterung. Geol. Bundesanstalt, Wien.

ŚLĄCZKA., GASIŃSKI A.M., BĄK M. and WESSELY G. (2009) - The clasts of Cretaceous marls in the conglomerates of the Konradsheim Formation (Pöchlau quarry, Gresten Klippen Zone, Austria). Geol. Carpath., 60 (2): 151-164.

TRAUTH F. (1950) - Die fazielle Ausbildung des Oberjura in den Nördlichen Ostalpen. Verh. Geol. B. A., Jg. 1948: 145-218.

WESSELY G. (2006) - Geologie der Österreichischen Bundesländer: Niederösterreich. Geologische Bundesanstalt.

WIDDER R.W. (1988) - Zur Stratigraphie, Fazies und Tektonik der Grestener Klippenzone zwischen Maria Neustift und Pechgraben. O. Ö. Mitt. Ges. Geol. Bergbaustud. Österr., 34/35: 79-133. 